\title{
THE ROLE OF PRE-RECRUITMENT PROCESSES IN THE MAINTENANCE OF A BARNACLE (Chthamalus challengeri HOEK) PATCH ON AN INTERTIDAL PEBBLE SHORE IN JAPAN
}

\author{
APOLINÁRIO, M. \\ Museu Nacional, Departamento de Invertebrados, Carcinologia, Universidade Federal do Rio de Janeiro, \\ CEP 20940-040, Rio de Janeiro, Brazil \\ Correspondence to: Moacir Apolinário, Departamento de Invertebrados, Carcinologia, Universidade Federal do Rio \\ de Janeiro, CEP 20940-040, Rio de Janeiro, Brazil, e-mail: a.moa@uol.com.br \\ Received October 17, 1997 - Accepted April 22, 1998 - Distributed June 30, 1999
}

(With 8 figures)

\begin{abstract}
To understand the role of pre-recruitment processes (supply of larvae and recruitment) in the maintenance of an intertidal barnacle (Chthamalus challengeri Hoek) patch, the availability of cyprid larvae and the recruitment on natural pebble substrata was monitored on the Magarisaki pebble shore (Amakusa, Kyushu, Japan) during 1995 and 1996. Also, a hypothesis that predation and/or bulldozing by mobile intertidal mollusks during the post-recruitment period could be an important factor in mortality of these barnacles was tested. The collapse of the adult population and the consequent disappearance of the patch were observed by the middle of 1995 . The larval availability was low

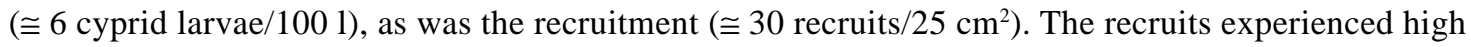
mortality, preventing them becoming adults able to maintain the patch. In 1996, a similar pattern of availability of the cyprid larvae, and even lower recruitment occurring only at the upper intertidal level was observed. A mobile mollusks exclusion experiment failed to detect any significant differences among the treatments, supporting the null hypothesis that the observed pattern of distribution was not caused by predation by mobile mollusks. There is my suggestion that the low availability of larvae and the low level of recruitment caused the non-maintenance of the patch.
\end{abstract}

Key words: barnacles, Chthamalus challengeri, larval supply, recruitment, Japan.

\section{RESUMO}

\section{O papel do recrutamento na manutenção de "patches" de cracas no litoral de Amakusa, Japão}

Para entender o papel dos processos pré-recrutamento (suprimento de larvas e recrutamento) na manutenção de um "patch" de uma craca da região entremarés (Chthamalus challengeri Hoek), foram monitorados a disponibilidade de larvas cipris e o recrutamento em substrato natural no litoral rochoso de Magarisaki (Amakusa, Kyushu, Japão) durante 1995 e 1996. Também foi testada a hipótese de que predação por moluscos móveis durante o pós-recrutamento poderia ser um importante fator na mortalidade destas cracas. Foi observado o colapso da população adulta e o conseqüente desaparecimento do "patch" em 1995. A disponibilidade de larvas foi baixa ( $\cong 6$ larvas cipris /100 1), assim como o recrutamento ( $\cong 30$ recrutas $/ 25 \mathrm{~cm}^{2}$ ). Os recrutas tiveram alta mortalidade, impedindo-os de se tornarem adultos capazes de manter o "patch". Em 1996, foi observado um padrão similar de disponibilidade de larvas cipris e um recrutamento ainda menor, ocorrendo apenas na região do supralitoral. A exclusão dos moluscos móveis não detectou nenhuma diferença significativa entre os tratamentos, suportando a hipótese nula de que o padrão de distribuição observado não é causado por predação por moluscos. É minha sugestão que a baixa disponibilidade de larvas e o baixo recrutamento causaram a não manutenção do "patch" de cracas.

Palavras-chave: Chthamalus challengeri, cracas, região entremarés, recrutamento, Japão. 


\section{INTRODUCTION}

The marine environment is usually divided by benthos and pelagos, with plankton being part of the pelagic world (Boero et al., 1996). The barnacles belong, in the early stages of their life cycle, to the plankton and, after successful metamorphosis and recruitment, they "become" benthic invertebrates. Their population dynamics are regulated mainly by the agents of mortality that act at each stage of their life history to restrict the number of individuals reaching reproductive maturity, as well as by the dispersal abilities of propagules and by availability of suitable recruitment sites (Minchinton \& Scheibling, 1991). Much research has been done to determine causes of differential mortality after recruitment: competition, predation, and physical disturbance (Connell, 1972, 1975; Paine, 1974, 1977, 1980, 1984; Menge \& Sutherland, 1976; Lubchenco \& Menge, 1978; Underwood et al., 1983). However, the barnacles have a larval phase of $2 \mathrm{wk}$ or more, and during that time the larvae are carried away from the system where they were released. The traditional population model assumes that the adults produce offspring, that become members of the same population as their parents, and so form a closed population, does not fit the above scenario.

Several recent studies on the small dispersing larval phase of marine invertebrates life cycles, have re-discovered Thorson's classic study (Thorson, 1950) and re-emphasized larval supply and early post-recruitment mortality as strong determinants of distribution and abundance of marine benthic populations (Yoshika, 1982; Keough, 1983; Underwood \& Denley, 1984; Watanabe, 1984; Gaines \& Roughgarden, 1985; Roughgarden et al., 1985, 1987; Menge \& Sutherland, 1987; Davis, 1988; Underwood \& Fairweather, 1989). A more realistic approach to population dynamics of marine invertebrates with pelagic larval phases, should assume that most of these populations are part of a multitude of geographically distant populations or metapopulations, and thus vulnerable of variations in the availability of cyprid larvae (due to oceanographic conditions or discontinuities in larvae release by the sub-populations) over time.

This study examined the mechanisms of patch maintenance of an intertidal barnacle (Chthamalus challengeri Hoek) population on a pebble shore. Since space was not a limiting factor at this intertidal pebble shore, and the barnacles were observed forming a unique isolated patch from the upper to the middle intertidal levels, there was a wish to know if pre- or post- recruitment processes were regulating the observed pattern of distribution, and if this pattern persisted over time and/or space.

\section{MATERIAL AND METHODS}

\section{Study site}

The sand spit of Magarisaki, located in Amakusa Shimoshima, West Kyushu, Japan (lat. 32Ү32'N, long. 130r02'E) (Fig. 1) is formed by oval pebbles, with an average diameter of $20 \mathrm{~cm}$, on corse sand (Takada \& Kikuchi 1990, 1991). The patches observed along the shore were of irregular size, extending from the middle to the upper intertidal zone. The shore is relatively protected in summer (June-September), with winds predominantly from south, but exposed during winter when winds are from the north (November-February). Tidal amplitudes vary between 0 and $300 \mathrm{~cm}$, with the middle intertidal defined as 150 to $200 \mathrm{~cm}$, and the upper intertidal at 100 to $150 \mathrm{~cm}$ below mean high tide level. Mean air and surface seawater temperature range from $6 \Upsilon$ to $33 \Upsilon$, and $13 \Upsilon$ to $26 \Upsilon \mathrm{C}$, respectively (Fig. 2).

\section{Recruitment}

At the upper and middle intertidal levels, ten $25 \mathrm{~cm}^{2}$ quadrats of 3 types were set up to monitor the recruitment and the adult population of the barnacle Chthamalus challengeri Hoek. The quadrats were set out on average size pebbles, with one quadrat per pebble, by drilling two $5 \mathrm{~mm}$ holes marking opposite corners of $5 \mathrm{~cm}$ square. Holes were drilled with a $12 \mathrm{~V}$ battery drill (National EZ 6101). The holes were used as reference points from which to take photographs at 2-3 d intervals during the main recruitment period, and at $2 \mathrm{wk}$ intervals throughout the year. A Nikon camera, with a Nikkor 35 mm 1:2 macro lens, and negative film (ASA 400), was used to take close-up photographs of each quadrat. The 3 types of quadrats were: 1) the control quadrats, used to monitor the adult population; 2) quadrats cleared only at the beginning of the experiment (succession), where each recruited individual was monitored until its death (as recognized by the disappearance of the opercular valve or the whole individual) to calculate survivorship; and 3) quadrats cleared at the beginning and after each photo-sampling, to monitor the number of recruits (Table 1). 


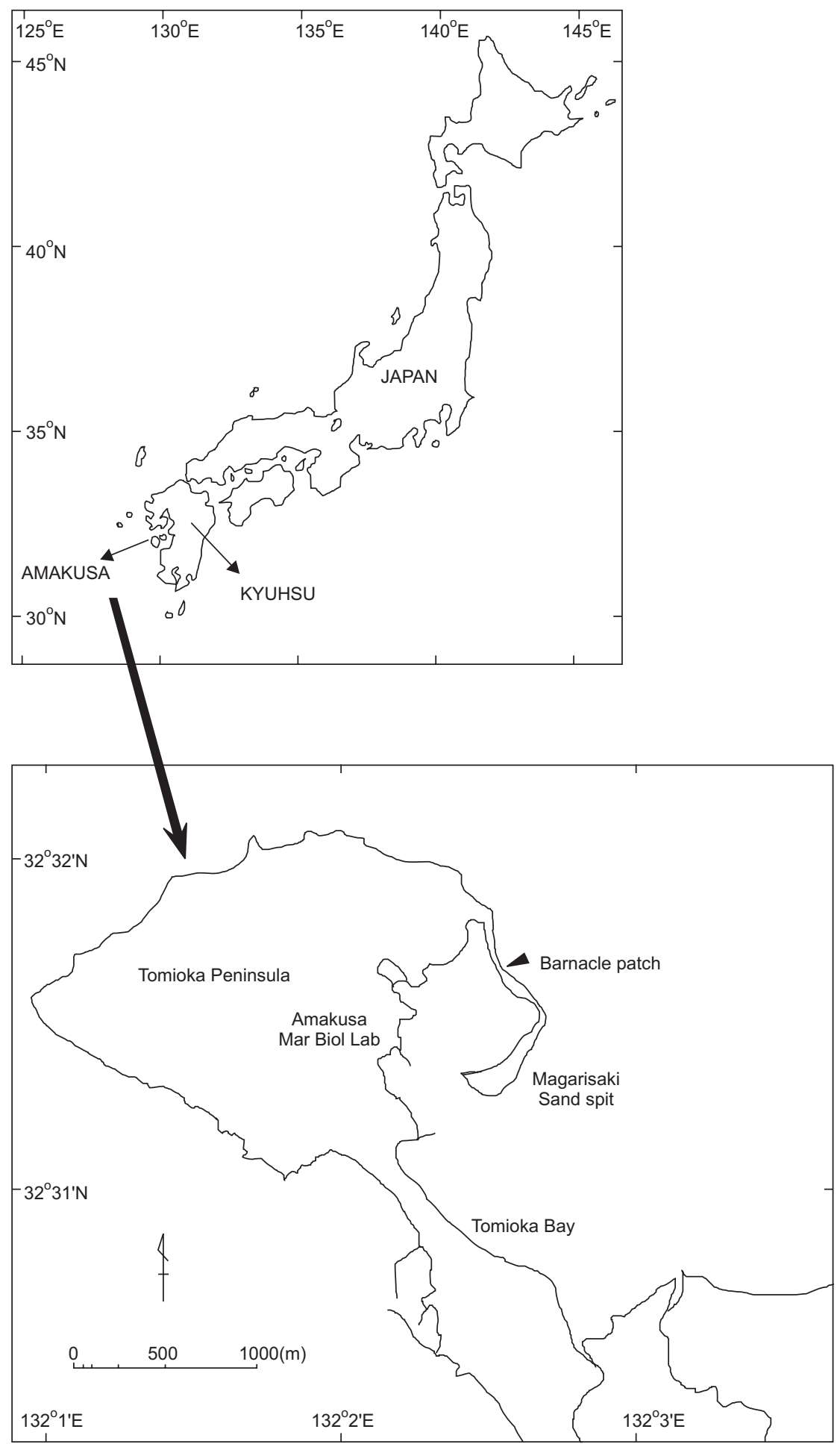

Fig. 1 - Maps locating the Amakusa Islands, in Kyushu, Japan (first from the top), and the Magarisaki Sand Spit at Tomioka Peninsula, Amakusa (second from the top). 


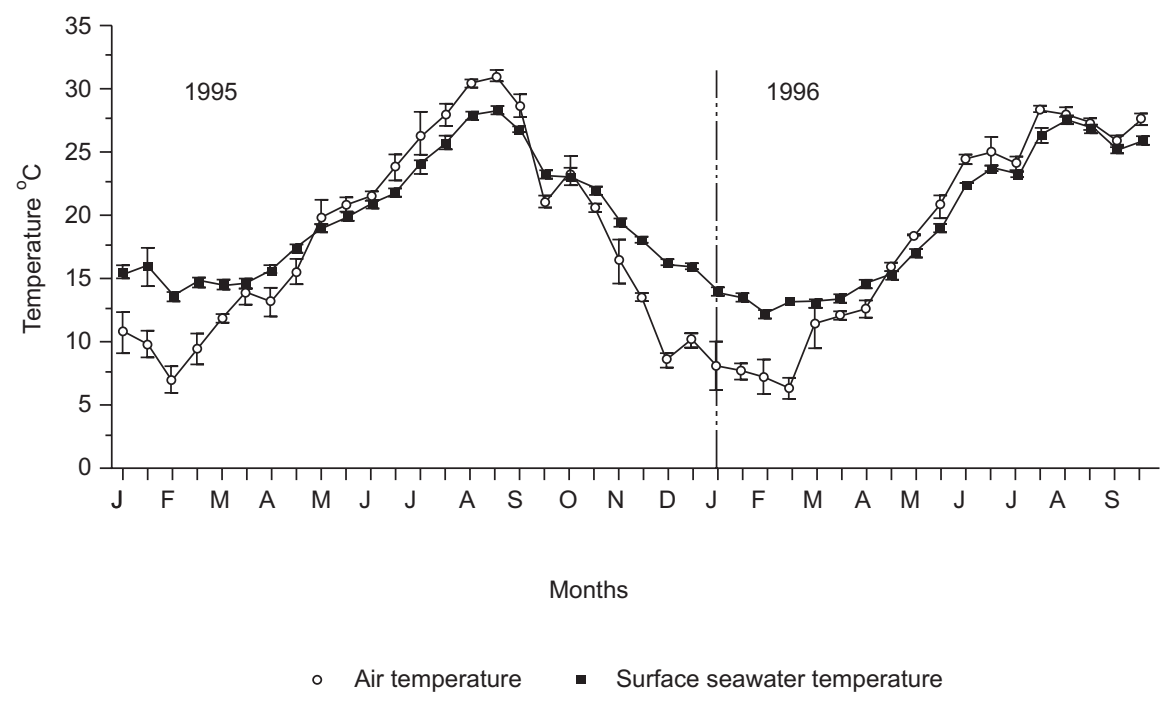

Fig. 2 - Mean (SD) air, and surface seawater temperatures for 1995 and 1996, until September.

TABLE 1

Photo-sampling design for the 3 types of ten $25 \mathrm{~cm}^{2}$ quadrats set up at the upper and middle intertidal levels.

\begin{tabular}{l}
\hline Type \\
Not cleared \\
\hline $\begin{array}{l}\text { Cleared only at the beginning } \\
\text { Cleared at the beginning, and after each } \\
\text { photo-sampling }\end{array}$ \\
\hline
\end{tabular}

In the laboratory, the film was developed, printed and used to calculated the numbers of adults and recruits, as well as the survivorship of the recruits. A digitizing device (USCON SQ 3100R2), connected with a micro-computer (NEC PC-9801), was used to analyze the close-up photographs and to assess the number and size of the barnacles in each quadrat over time.

Data for the number of adults and recruits underwent square root transformation to ensure the equality of the variances before running a twoway ANOVA to assess the significance of the differences between and within intertidal levels and over time. The survivorship was calculated by transforming the numbers of survivors into frequency data.

\section{Larval supply}

The density of cyprid larvae was estimated weekly and at 2-3 d intervals during the main

\begin{tabular}{c|c|}
\hline Name & Data \\
\cline { 2 - 2 } Control & Adult population \\
\hline Succession & Survivorship of recruits \\
Recruits & Recruitment \\
\hline
\end{tabular}

recruitment period, and twice a day (at 10:00 and 16:00) during May 1, 2, 9, and 24. During 1995, estimates were obtained from plankton samples by filtering 1001 of seawater collected at $0.5 \mathrm{~m}$ through a $150 \mu \mathrm{m}$ mesh plankton net with a battery-powered pump (Hitachi $12 \mathrm{~V}$ ). Three replicate plankton samples were taken during daylight from a boat anchored in front of the recruitment quadrat sites and fixed in $4 \%$ buffered formalin. Because of the batterypowered pump's low filtration capacity, in 1996, the pump was changed to a gasoline-powered model (Makita EPR 230). With the new pump, the plankton was sampled in triplicate from 2 different depths $(0.5$ and $3.5 \mathrm{~m})$. The difference of filtration power between the 2 pumps was corrected by standardizing the cyprid larvae density to a density of 1 cyprid/ 1001 for both sampling methods.

Cyprid density data underwent square root transformation to ensure the equality of variances before running a one-way (1995, at $0.5 \mathrm{~m}$ ) and two- 
way (1996, at 0.5 and $3.5 \mathrm{~m}$ ) ANOVA, to assess the significance of the differences between and within sampling depths, and over time. Kendall's coefficient rank of correlation $(\tau)$, was used to examine the relationship between weekly planktonic cyprid densities (CD) for the 2 different depths in the water column during 1995 and 1996, and weekly densities of recruits (RD) at the upper and middle intertidal levels over an 8 wk period $(\mathrm{n}=8)$. The significance of $\tau$ for samples sized up to 40 was tested by using the table corrected for ties given in Burr (1960).

\section{Mobile mollusks exclusion's experiment}

A 4-fence type experiment was carried out to test the hypothesis that post-recruitment mortality, caused by predation by a mobile mollusk (Thais clavigera Küster), is an important factor controlling the population of the barnacle Chthamalus challengeri Hoek, at the Magarisaki intertidal pebble shore. The fences were set up at the upper and middle intertidal levels, with 4 replicates for each fence type before the main recruitment period (the beginning of March 1996). The fences were made of $40 \infty 15 \infty 15 \mathrm{~cm}$ plastic boxes cut on the bottom and sides (like windows), and fixed with $2 \mathrm{~mm}$ mesh net fixed over those windows. The pebbles were carefully put into the experimental areas without the mobile mollusks (depending on the treatment). During the first weeks, some mobile gastropods (including the carnivorous $\mathrm{T}$. clavigera), could climb the fences into the experimental areas.

To avoid this problem, a third fence type was used, painted on the outside parts with a tin based paint (anti-fouling red paint). To check the effects of the paint on the recruitment, another painted fence without the $2 \mathrm{~mm}$ mesh nets (open fence + paint) was set up among the 3 other fence types (Table 2). The efficiency of the tin based paint in preventing the molluks from climbing the fences into the experimental areas was confirmed by field observations.

From the start of the recruitment period (early June), 4 replicated, close-up photographs were taken from inside of each fence type, using the same method described above for the recruitment. For each of the 2 observed recruitment peaks, the cohorts were followed until 5-6 wk of age. Data underwent square root transformation to ensure the equality of the variances, before being transformed into frequency data, followed by arcsine transformation to run a two-way ANOVA to assess the significance of the differences between and within the treatments and over time.

\section{RESULTS}

\section{Recruitment}

The population density of adults with opercular length greater than $1 \mathrm{~mm}$ declined drastically since January 1995 until reaching zero, in August 1995 (Fig. 3). There were no significant differences between the densities of the adults at the upper and middle intertidal levels (Table 3 ). In 1996, there were no more visible barnacle patches, even though recruitment was observed at both intertidal levels from May to July, 1995, and at the upper intertidal from June to July in 1996; being the peak of the recruitment in June for both years (Fig. 4).

There was a significant difference between the densities of recruits between the 2 intertidal levels, especially in 1996, when there was recruitment only at the upper intertidal level (Table 3). The non-recovery of the adult population in 1996 is explained by the high mortality of newcomers recruited in 1995. The 4 followed cohorts (recruited in May 31, June 6, 13, and July 11) experienced high mortality, especially for the latest recruits and just survived until the end of November (Fig. 5).

TABLE 2

Experimental design to investigate the early post-recruitment mortality of the barnacle Chthamalus challengeri Hoek during the main recruitment period for 4 different fence types, and its possible effects on the barnacle recruitment.

\begin{tabular}{|c|c|c|c|}
\hline Treatments & Mobile mollusks & Effect of the paint & Effect of the fence \\
\hline Febce + Paint $(F+P)$ & Excluded & Yes & Yes \\
\hline Fence $(\mathrm{F})$ & Partially excluded & No & Yes \\
\hline Open Fence + Paint $(\mathrm{OF}+\mathrm{P})$ & Allowed in & Yes & No \\
\hline Open $(\mathrm{O})$ & Allowed in & No & No \\
\hline
\end{tabular}




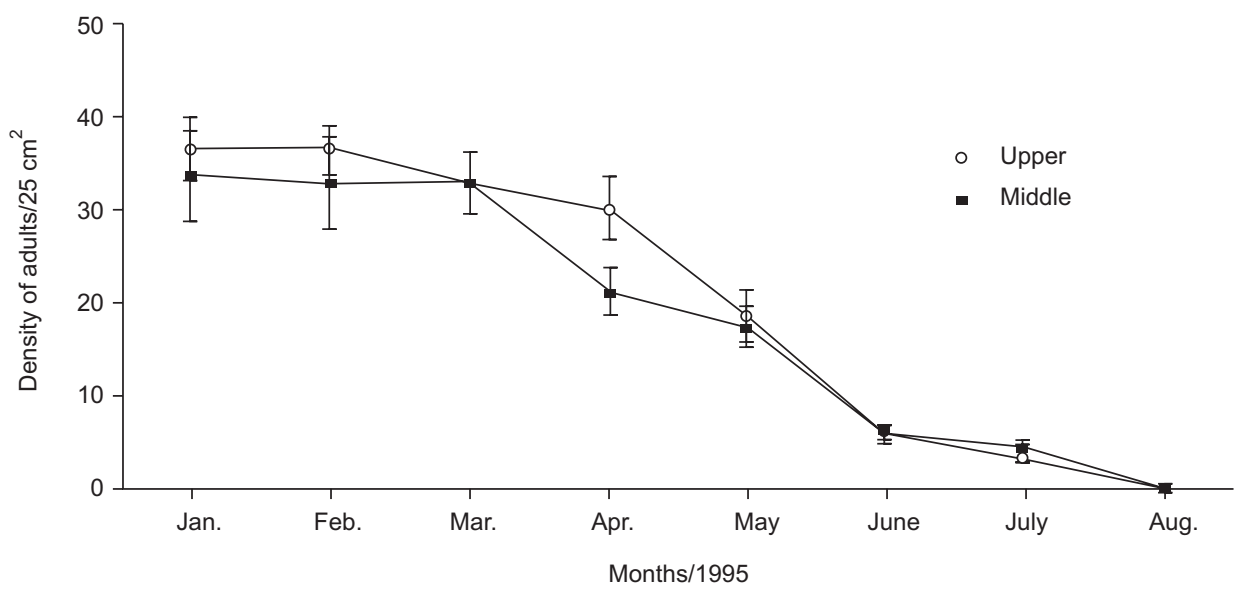

Fig. 3 - Mean (SD) density of adult barnacles sampled from ten $25 \mathrm{~cm}^{2}$ quadrats (control), at the upper, and middle intertidal levels since January, 1995.

\section{TABLE 3}

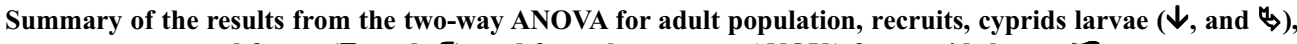
and fences $(\kappa$, and $\mathcal{F})$, and from the one-way ANOVA for cyprids larvae $\mathbb{P}$.

\begin{tabular}{|c|c|c|c|c|}
\hline Source & & df & $\mathbf{F}$ & $\mathbf{P}$ \\
\hline \multirow[t]{4}{*}{$\overline{\text { Adult population }}$} & & & & \\
\hline & Time & 7 & 58.62 & $0.0001 * * *$ \\
\hline & Int. level (Upper vs. Midle) & 1 & 1.82 & $0.1790 \mathrm{NS}$ \\
\hline & Int. level vs. Time & 7 & 0.73 & $0.6448 \mathrm{NS}$ \\
\hline \multirow[t]{4}{*}{ Recruits } & & & & \\
\hline & Time & 11 & 125.96 & $0.0001 * * *$ \\
\hline & Int. level (Upper vs. Midle) & 1 & 28.46 & $0.0001 * * *$ \\
\hline & Int. level vs. Time & 11 & 6.26 & $0.0001 * * *$ \\
\hline \multirow[t]{8}{*}{ Cyprids larvae } & & & & \\
\hline & (1) Time & 13 & 11.95 & $0,0001 * * *$ \\
\hline & (2) Time & 13 & 22.13 & $0.0001 * * *$ \\
\hline & (2) Depths ( $0.5 \mathrm{~m}$ vs. $3.5 \mathrm{~m})$ & 1 & 53.48 & $0.0001 * * *$ \\
\hline & (2) Depths vs. Time & 13 & 9.07 & $0.0001 * * *$ \\
\hline & (3) Days & 6 & 14.72 & $0.0001 * * *$ \\
\hline & (3) Depths $(0.5 \mathrm{~m}$ vs. $3.5 \mathrm{~m})$ & 1 & 6.30 & $0.0181 *$ \\
\hline & (3) Depths vs. Days & 6 & 1.87 & $0.1221 \mathrm{NS}$ \\
\hline \multirow[t]{7}{*}{ Fences } & & & & \\
\hline & (4) Time & 9 & 599.74 & $0.0001 * * *$ \\
\hline & (4) Treatments (4 fence types) & 3 & 0.86 & $0.4608 \mathrm{NS}$ \\
\hline & (4) Treatment vs. Time & 27 & 0.25 & $0.9999 \mathrm{NS}$ \\
\hline & (5) Time & 9 & 689.21 & $0.0001 * * *$ \\
\hline & (5) Treatments (4 fence types) & 3 & 0.52 & $0.6689 \mathrm{NS}$ \\
\hline & (5) Treatment vs. Time & 27 & 0.36 & $0.9983 \mathrm{NS}$ \\
\hline
\end{tabular}

*** Significantly different at 0.001 level, * significantly different at 0.05 level, and NS not significantly different.

(1) - Data from density of cyprid larvae at $0.5 \mathrm{~m}$, in 1995 (Fig. 4a)

(2) - Data from density of cyprid larvae at $0.5 \mathrm{~m}$, and 3,5 m, in 1996 (Fig. 4b).

(3) - Data from density of cyprid larvae at $0.5 \mathrm{~m}$, and $3.5 \mathrm{~m}$ sampled twice a day, during May, 1996 (Fig. 4c).

(4) and (5) - Arcsine transformed data from the two survivorship curves, during the

4 fence types experiment (Fig. 5), respectively. 


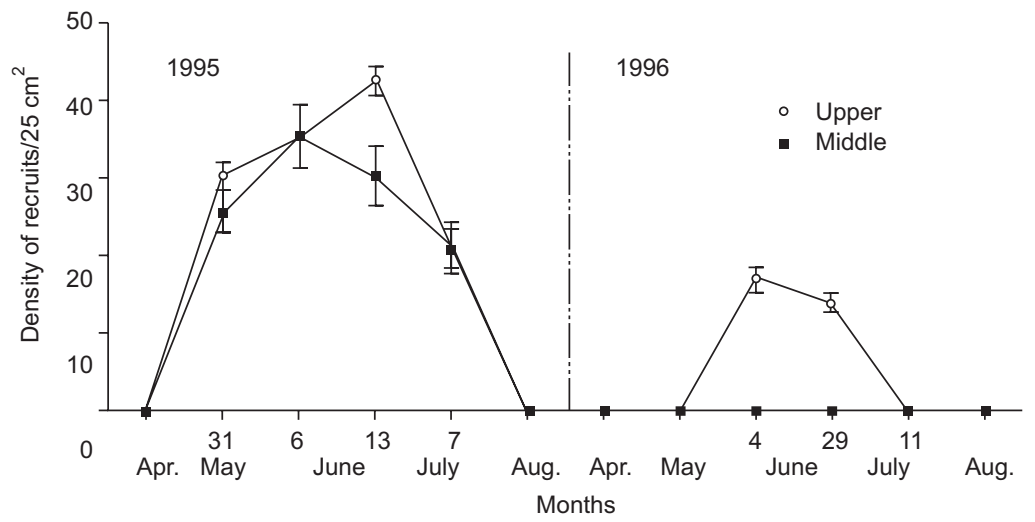

Fig. 4 - Mean (SD) density of recruits barnacles sampled from ten $25 \mathrm{~cm}^{2}$ quadrats (recruits), at the upper, and middle intertidal levels during 1995 and 1996.

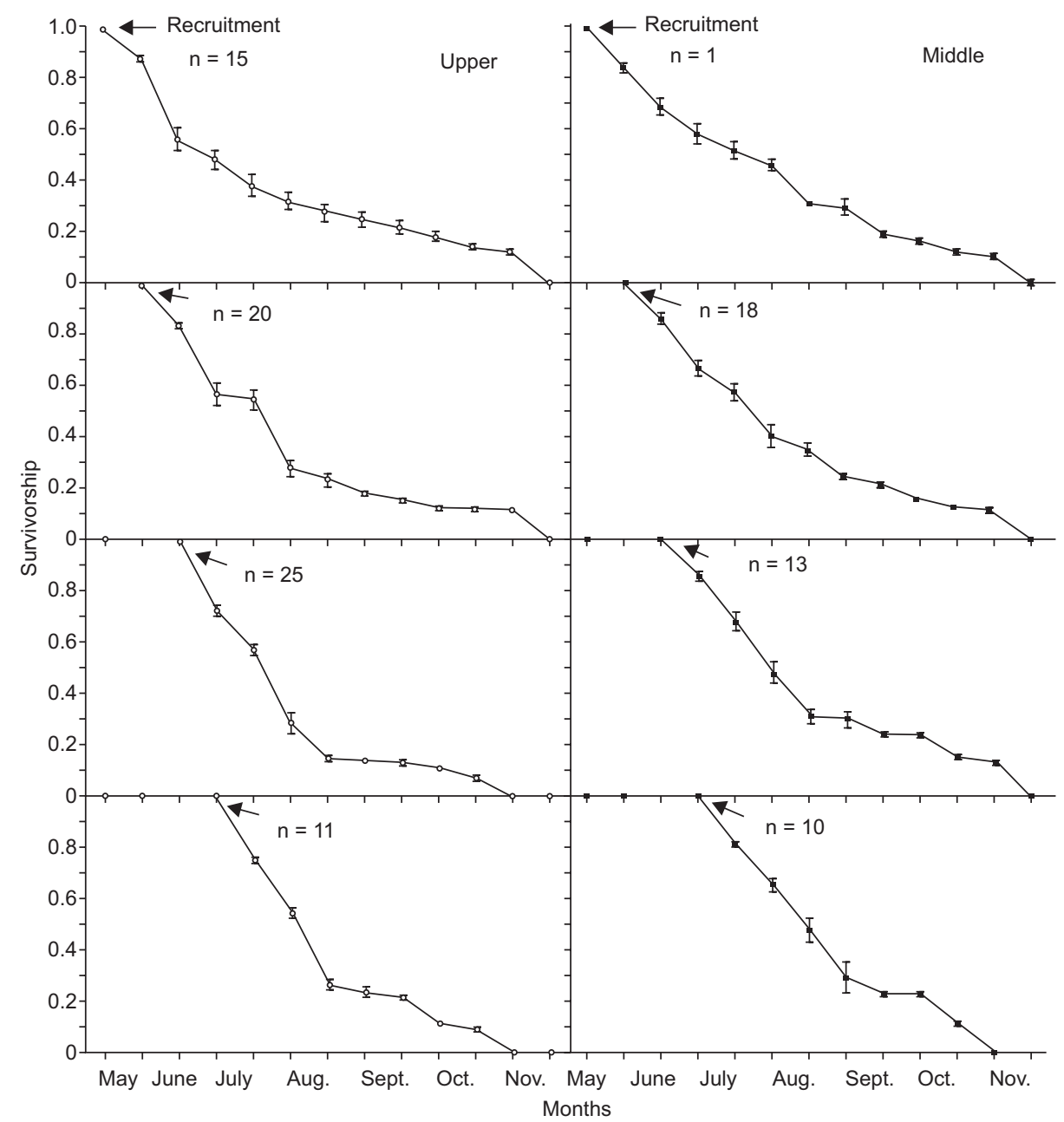

Fig. 5 - Survivorship curves of the 4 cohorts ( 4 recruitment peaks), during the main recruitment period of 1995 at the upper and middle intertidal levels. The individuals (n) were monitored until their death by consecutive photo-sampling taken from the succession quadrats. 


\section{Larval supply}

In 1995, cyprid larvae at $0.5 \mathrm{~m}$, were available from the beginning of May until the beginning of July. The peak of density of cyprid larvae was $\cong 7 / 1001$, in the middle of June (Fig. 6a). This represents a very low density of cyprid larvae available during the main recruitment period of 1995. For the next year, sampling from both 0.5 and $3.5 \mathrm{~m}$ depths, reveled that cyprid larvae was $\cong 9 / 100 \mathrm{l}$, in the beginning of May, following a second consecutive year of low availability of cyprid larvae during the main recruitment period (Fig. 6b). There was a significant difference between the densities of cyprids from 0.5 and $3.5 \mathrm{~m}$ (Table 3 ). Actually, very few cyprids were sam- pled from $3.5 \mathrm{~m}$, confirming the neustonic habitat of the cyprid larvae (Le Fèvre \& Bouget, 1992). Also, for the samples taken twice a day, there was a significant difference between the 2 sampling depths, with the cyprid larvae's density peaking at 16:00 in May 2 (Fig. 6c).

For 1995 , weekly cyprids densities at $0.5 \mathrm{~m}$ were significantly correlated with weekly recruited densities at the upper intertidal level (Kendall's coefficient rank of correlation $(\tau)$ significant at 0.01 level). Weekly cyprids densities at $3.5 \mathrm{~m}$ in 1996 were also significantly correlated ( 0.05 level) with the densities of recruits at the upper intertidal level, although the number of cyprid larvae at this depth ranged from 0 to 4 (Table 4 ).

TABLE 4

Summary of results from Kendall's coefficient rank of correlation $(\tau)$ between weekly planktonic cyprid density (CD) (during 1995 and 1996, at 0.5 and $3.5 \mathrm{~m}$ depths), and weekly recruits density (RD), at different intertidal levels (upper and middle) over an 8 wk period $(n=8)$.

\begin{tabular}{|c|c|c|ccc|}
\hline \multicolumn{2}{|c}{$\begin{array}{c}\text { Abundances compared } \\
\text { (CD vs. RD) }\end{array}$} & $\tau$ & p \\
1995 & at $0.5 \mathrm{~m}$ & vs. Upper & 0.84 & 0.004 \\
& & vs. Middle & 0.49 & 0.090 \\
\hline \multirow{2}{*}{1996} & at $0.5 \mathrm{~m}$ & vs. Upper & 0.44 & 0.123 \\
\hline & & vs. Middle & - & - \\
\cline { 5 - 6 } & at $3.5 \mathrm{~m}$ & & vs. Upper & 0.70 & 0.015 \\
\hline
\end{tabular}

\section{Mobile mollusks exclusion's experiment}

In 1996, there was recruitment only at the upper intertidal level. Despite the low recruitment (see Fig. 4), it was possible to assess and follow 2 cohorts, one with its recruitment peak in June 4 and the other in June 29. Both had a very low survivorship with a big drop during the first week, followed by a small tendency to stabilize at 0.21 of the total recruitment by the end of wk 4 or 5 (Fig. 7).

There were no significant differences in survivorship among the 4 fence types, for either cohort (Table 3), and mortality during the first wk represented an average of $50 \%$ of the total recruitment (Fig. 8). The lack of significant differences among the 4 fence types can be explained by the low density of mobile mollusks during this experiment (Table 5), and especially by the low density of the carnivorous $\mathrm{T}$. clavigera, that represents the most important predator of the barnacle $\mathrm{C}$. challengeri Hoek in this pebble shore.

\section{DISCUSSION}

At the beginning of this study, the barnacle patch was composed exclusively by adults surrounded by empty tests of dead individuals, which consisted of more than $50 \%$ of the total cover of the barnacle patch. The adult barnacles experienced high mortality, until they had disappeared by the end of July 1995. The recruitment in 1995 took place from May to July only within the limits of the barnacle patch, even though the area of the patch was drastically reduced. It is well documented that many barnacle species tend to select their microhabitats by chemical cues (Pawlik, 1992; ZimmerFaust \& Tamburri, 1994) or by directly recruiting on adult individuals (Miron et al., 1996). 
TABLE 5

Mean (SD) density of the mobile mollusks at the upper intertidal level inside each fence type (4 replicates), during the main recruitment period.

\begin{tabular}{|c|c|c|c|c|}
\hline \multirow[t]{2}{*}{ Treatments } & \multicolumn{4}{|c|}{ Mean (SD) density of mobile mollusks } \\
\hline & T. clavigera & L. cronata coreana & M. labio & Nerita $\mathrm{sp}$ \\
\hline Fence + Paint $(\mathrm{F}+\mathrm{P})$ & - & - & - & - \\
\hline Fence $(\mathrm{F})$ & $2(5)$ & $3(4)$ & $14(10)$ & $8(15)$ \\
\hline Open Fence + Paint $(\mathrm{OF}+\mathrm{P})$ & $8(6)$ & $7(3)$ & $13(6)$ & $20(5)$ \\
\hline Open $(\mathrm{O})$ & $6(4)$ & $5(6)$ & $10(4)$ & $16(2)$ \\
\hline
\end{tabular}
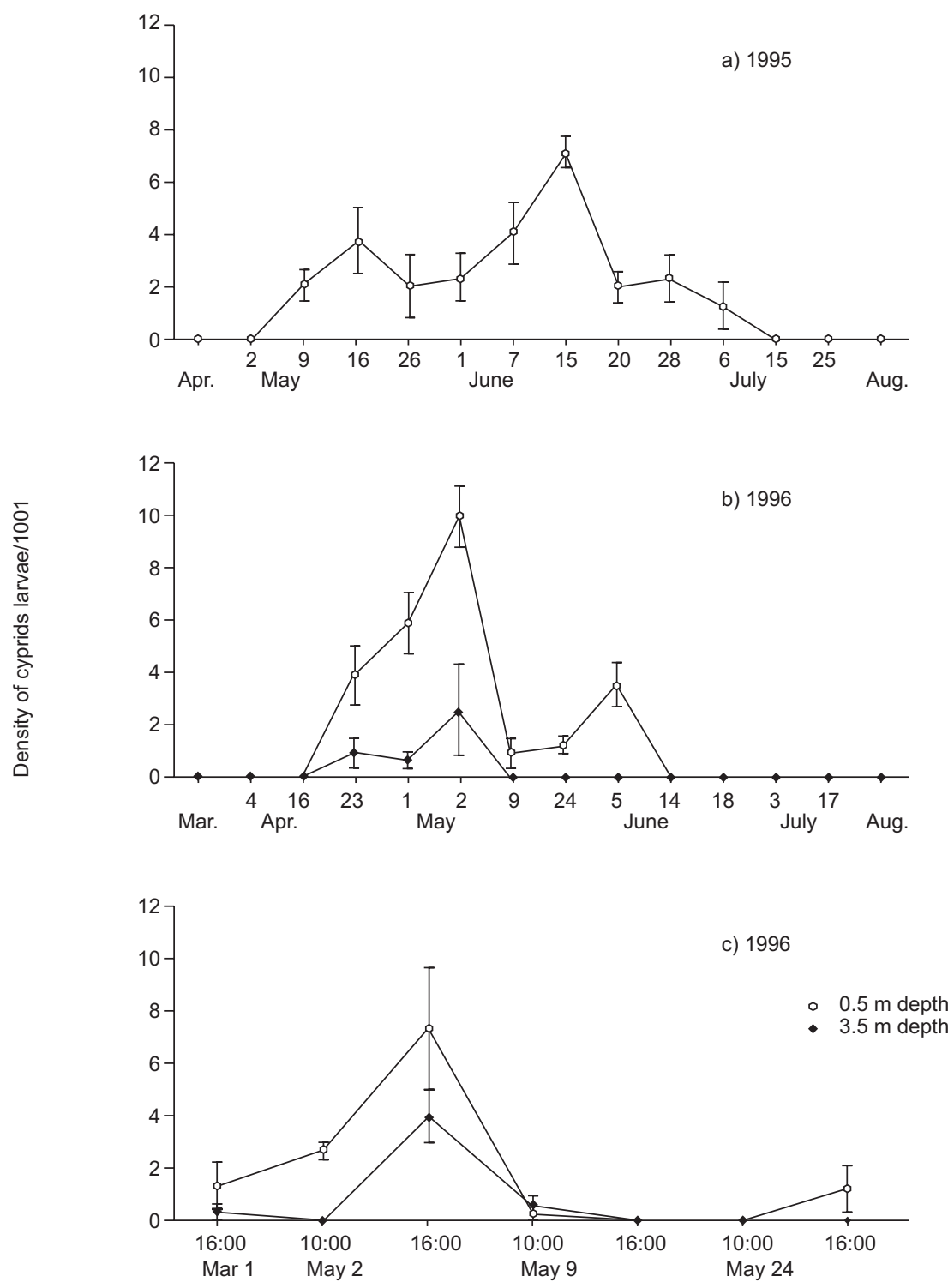

Fig. 6 - Mean (SD) density of cyprid larvae/100 1, sampled from the water column at $0.5 \mathrm{~m}$ depth in 1995 (a); $0.5 \mathrm{~m}$, and $3.5 \mathrm{~m}$ depths in 1996 (b); and at $0.5 \mathrm{~m}$ and $3.5 \mathrm{~m}$ depths, twice a day, in May, 1996 (c) (all in replicates). 


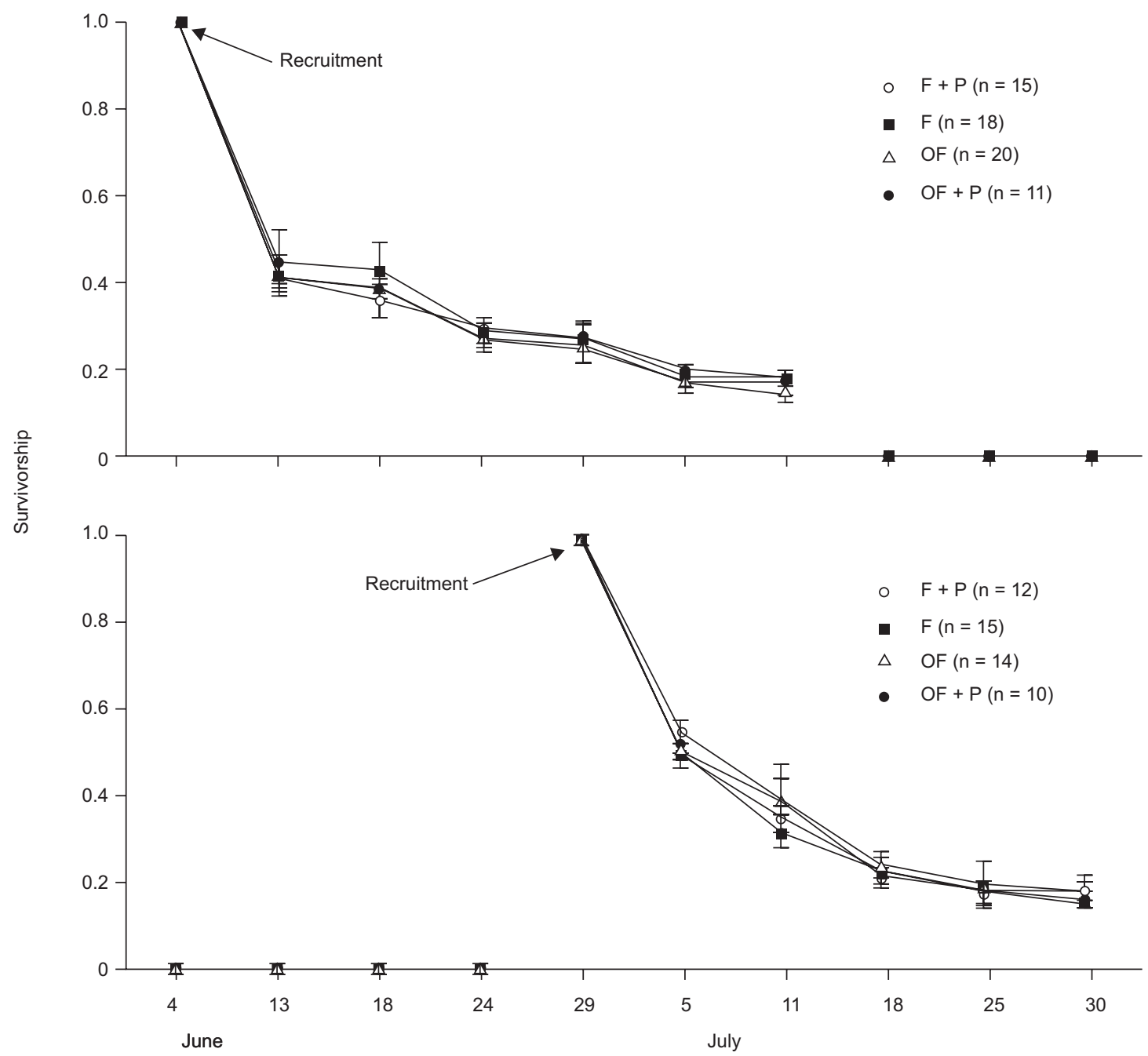

Fig. 7 - Survivorship of the 2 cohorts ( 2 recruitment peaks) inside each fence type during the main recruitment period in 1996. The fences are: Fence + Paint $(F+P)$, Fence $(F)$, Open Fence $(O F)$, and Open Fence + Paint $(O F+P)$.

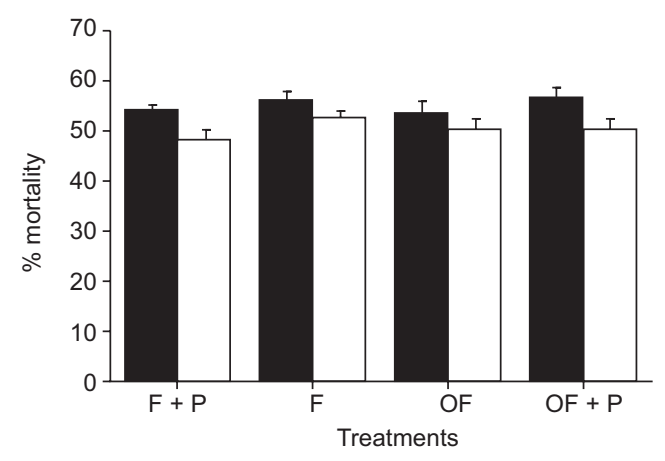

- First cohort $\square$ Second cohort

Fig. 8 - Mortality rates of the 2 cohorts inside each fence type, during the first week after recruitment. Fence + Paint $(F+$ $\mathrm{P})$, Fence $(\mathrm{F})$, Open Fence $(\mathrm{OF})$, and Open Fence + Paint $(\mathrm{OF}+\mathrm{P})$. 
Also reported are interactions with conspecific larvae (Yule \& Walker, 1987; Clare et al., 1994), and with microbial films (Neal \& Yule, 1994; Wieczoreck et al., 1995). The photographs taken to monitor and measure the barnacles, show recruitment occurring preferentially in the neighborhood of adult individuals (alive or empty tests) and a tendency to form patches.

The density of cyprid larvae on the water column adjacent to the recruitment sites correlated significantly with the density of recruitment at the upper intertidal level, but it failed to correlate with the recruitment at the middle intertidal level. This difference is due to the differences between the recruitment at the 2 intertidal levels. Both the availability of cyprid larvae and the recruitment were very low when compared with data from other studies; see Minchinton \& Scheibling (1991), Gaines \& Bertness (1993), and Satchell \& Farrell (1993) for data about availability, and Mori (1990), Sutherland (1990), and Satchell \& Farrell (1993) for data about recruitment. The following year, the recruitment was lower and occurred only at the upper intertidal level; and the density of cyprid larvae sampled from $0.5 \mathrm{~m}$ showed a pattern similar to that observed the year before. The significant correlation between the cyprid larvae sample from $3.5 \mathrm{~m}$, and the recruitment at the upper intertidal level, can be explained by the low availability of the cyprid larvae at this depth.

The individuals recruited in 1995 had a high mortality and could maintain neither the population nor the previously observed patch (despite recruitment having occurred only within patch limits). This results differs from Carrol (1996), who reported high survival to adulthood during a low recruitment year, permitting the maintenance of the population. The mortality of the recruits in 1996 was even higher, with a lost of nearly $50 \%$ of the total recruitment by the first week. The fence experiment failed to detect any significant effect of predation and/or bulldozing by gastropods as the main cause of the post-recruitment mortality. Gosselin \& Qian (1996) suggest that micropredators such as protozoan and nematodes could be a potential cause of high mortality during the first days after recruitment, but no experimental data supporting this hypothesis is available. Patterns of mortality can differ significantly between rocky and pebble shores, with the later being more susceptible to disturbance by wave action and human activity.

Desiccation, especially at the upper intertidal levels, is an important factor of mortality in the post-recruitment period, but is not sufficient to explain alone the decline of an adapted intertidal population. It is my suggestion that pre-recruitment processes, such as the low availability of cyprid larvae during the main recruitment period and the consequent low recruitment, could be potential causes of the decline and non-maintenance of this barnacle patch. Considering that this sub-population is part of a meta-population, we can expect the recover of this patch and/or formation of new patch(es) in subsequent periods. Further studies could determine whether the decline of this subpopulation is just a cyclical down phase.

Acknowledgements - I express my sincere gratitude to Prof. Taiji Kikuchi for giving me the chance to develop this project in Japan, and to my advisor Dr. Keisuke Mori for his valuable suggestions and teachings. I also express my gratitude to $\mathrm{Mr}$. Teruo Sameshima for his technical support during the plankton sampling and the making of fences for field experimentation. Thanks to all professors, colleagues, and staff members at the Amakusa Marina Biological Laboratory who helped me to settle in the town and develop my research. Thanks also to Dr. Richard Weisburd and Dr. Jay Maclean for English language revision. The Japanese Ministry of Science and Culture (MONBUSHO) provided financial assistance for my stay in Japan.

\section{REFERENCES}

BOERO, F., BELMONTE, G., FANELLI, G., PIRAINO, S. \& RUBINO, F., 1996, The continuity of living matter and the discontinuities of its constituents: do plankton and benthos really exist? Tree, 11: 177-180.

BURR, E. J., 1960, The distribution of Kendall's score S for a pair of tied rankings. Biometrika, 47: 151-171.

CARROL, M. L., 1996, Barnacle population dynamics and recruitment regulation in south-central Alaska. J. Exp. Mar. Bio. Ecol., 199: 285-302.

CLARE, A. S., FREET, R. K. \& MCCLARY Jr., M., 1994, On the antennular secretion of the cyprid of Balanus amphitrite amphitrite, and its role as a settlement pheromone. J. Mar. Biol. Ass. UK., 74: 243-250.

CONNELL, J. H., 1972, Community interactions on marine rocky intertidal shores. Annu. rev. Ecol. Syst., 3: 169-192.

CONNELL, J. H., 1975, Some mechanisms producing structure in natural communities: a model and evidence from field experiments. pp. 460-490. In: M. L. Cody \& Diamond (eds.), Ecology of evolution and communities, Belknap, Cambridge, Massachusetts, USA. 
DAVIS, A. R., 1988, Effects of variation in initial settlement on distribution and abundance of Podoclavella mollucensis Sluiter. J. Exp. Mar. Bio. Ecol., 117: 157-167.

GAINES, S. \& BERTNESS, M.,1993, The dynamics of juvenile dispersal: why field ecologists must integrate. Ecology, 74(8): 2430-2435.

GAINES, S., BROWN, S. \& ROUGHGARDEN, J., 1985, Spatial variation in larval concentrations as cause of spatial variation in settlement for the barnacle, Balanus glandula. Oecologia (Berlin), 67: 267-272.

GOSSELIN, L. A. \& QIAN, P. Y., 1996, Early post-settlement mortality of an intertidal barnacle: a critical period of survival. Mar. Ecol. Prog. Ser., 135: 69-75.

KEOUGH, M. J., 1983, Patterns of recruitment of sessile invertebrates in two subtidal habitats. J. Exp. Mar. Bio. Ecol., 66: 213-245.

LE FÈVRE, J. \& BOURGET, E., 1992, Hydrodynamics and behavior: transport processes in marine invertebrate larvae. Trends in Ecology and Evolution, 7(9): 288-289.

LUBCHENCO, J. \& MENGE, B. A., 1978, Community development and persistence in a low rocky intertidal zone. Ecol. Monogr., 48: 67-94.

MENGE, B. A. \& SUTHERLAND, J. P., 1976, Species diversity gradients: synthesis of the role of predation, competition and temporal heterogeneity. Am. Nat., 110: 351-369.

MENGE, B. A. \& SUTHERLAND, J. P., 1987, Community regulation: variation in disturbance, competition and predation in relation to environmental stress and recruitment. Am. Nat., 130: 730-757.

MINCHINTON, T. E. \& SCHEIBLING, R. E., 1991, The influence of larval supply and settlement on the population structure of barnacles. Ecology, 72(5): 1867-1879.

MIRON, G., BOUDREAU, B. \& BOURGET, E., 1995, Use of larval supply in benthic ecology: testing correlation between larval supply and larval settlement. Mar. Ecol. Prog. Ser., 124: 301-305.

MIRON, G., BOURGET, E. \& ARCHAMBAULT, P., 1996, Scale of observation and distribution of adult conspecific: their influence in assessing passive and active settlement mechanisms in the barnacle Balanus crenatus (Brugière). J. Exp. Mar. Bio. Ecol., 201: 137-158.

MORI, K., 1990, Vertical variations of larval release and settlement of the intertidal barnacle Chthamalus challengeri Hoek. La Mer, 28: 180-187.

NEAL, A. L. \& YULE, A. B., 1994, The interaction between Elminius modestus Darwin cyprids and biofilms of Deleya marina NCMB 1877. J. Exp. Mar. Bio. Ecol., 176: 127-139.

PAINE, R. T., 1974, Intertidal community structure: experimental studies on the relationship between a dominant competitor and its principal prey. Oecologia (Berlin), 15: 93-120.
PAINE, R. T., 1977, Controlled manipulations in the marine intertidal zone, and their contribution to ecological theory, pp. 245-270. In: C. E. Goulden (ed.), The changing scenes in natural sciences, 1776-1976, Special publication 12, The Academy of Natural Sciences of Philadelphia, Fulton, Lancaster, Pennsylvania, USA.

PAINE, R. T., 1980, Food webs: linkage, interaction strength and community infra-structure. J. Exp. Mar. Bio. Ecol., 49: 667-685.

PAINE, R. T., 1984, Ecological determinism in competition for space. Ecology, 65: 1339-1357.

PAWLIK, J. R., 1992, Chemical ecology of the settlement of benthic marine invertebrates. Oceanogr. Mar. Biol. Annu. Rev., 30: 273-335.

ROUGHGARDEN, J., IWASA, Y. \& BAXTER, C., 1985, Demographic theory for an open marine population with space limited recruitment. Ecology, 66: 54-67.

ROUGHGARDEN, J., GAINES, D. \& PACALA, S. W., 1987, Supply-side ecology: the role of physical transport processes, pp. 491-581. In: P. Giller \& J. Gee (eds.), Organization of communities: past and present, Proceedings of the British Ecological Society Symposium, Aberystwyth, Wales (April, 1986), Blackwell Scientific, London, England.

SATCHELL, E. R. \& FARRELL, T. M., 1993, Effects of settlement density on spatial arrangement in four intertidal barnacles. Mar. Biol., 116: 241-245.

SUTHERLAND, J. P., 1990, Recruitment regulates demographic variation in a tropical intertidal barnacle. Ecology, 71(3): 955-972.

TAKADA, Y. \& KIKUCHI, T., 1990, Mobile molluscan communities in boulder shores and the comparison with other habitats in Amakusa. Publ. Amakusa Mar. Biol. Lab., 10: 145-168.

TAKADA, Y. \& KIKUCHI, T., 1991, Seasonal and vertical variation of the boulder shore fauna in Amakusa. Publ. Amakusa Mar. Biol. Lab., 11(1): 1-17.

THORSON, G., 1950, Reproductive and larval ecology of marine invertebrates. Biol. Rev. Cambr. Phil. Soc., 25: 1-45.

UNDERWOOD, A. J. \& DENLEY, E. J., 1984, Paradigms, explanations and generalizations in models for the structure of intertidal communities on rocky shores, pp. 151180. In: D. R. Strong, D. Simberloff, L. G. Abele \& A. B. Thistle (eds.), Ecological communities: conceptual issues and evidence, Princeton University Press, Princeton, New Jersey, USA.

UNDERWOOD, A. J., DENLEY, E. J. \& MORAN, M. J., 1983, Experimental analysis of the structure and dynamics of mid-shore rocky intertidal communities in New South Wales. Oecologia (Berlin), 56: 202-219. 
UNDERWOOD, A. J. \& FAIRWEATHER, P. G., 1989, Supply-side ecology and benthic marine assembles. Tree, 4 : 16-20.

WATANABE, J. M., 1984, The influence of recruitment, competition and benthic predation on spatial distributions of three species of kelp forest gastropods (Trochidae: Tegula). Ecology, 65: 920-936.

WIECZORECK, S. K., Clare, A. S. \& Tood, C. D., 1995, Inhibitory and facilitatory effects of microbial films on settlement of Balanus amphitrite amphitrite larvae. Mar. Ecol. Prog. Ser, 119: 221-228.
YOSHIOKA, P. M., 1982, Role of planktonic and benthic factors in the population dynamics of the bryozoan, Membranipora membranacea. Ecology, 63: 457-468.

YULE, A. B. \& WALKER, G., 1987, Adhesion in barnacles. In: A. J. Southward (ed.), Barnacle Biology, Bakema, Rotterdan, 389-402.

ZIMMER-FAUST, R. K. \& TAMBURRI, M. N., 1994, Chemical identity and ecological implications of a waterborne, larval settlement cues. Limnol. Oceanogr., 39: 1075-1087. 